\title{
PRIMARY TOTAL HIP REPLACEMENT IN PATIENTS OVER 80 YEARS OF AGE
}

\author{
D. P. NEWINGTON, G. C. BANNISTER, M. FORDYCE
}

From Winford Orthopaedic Hospital, Bristol

\begin{abstract}
We have reviewed 107 patients of 80 years or over who underwent primary total hip replacement. They had many more complications than younger patients. Thus, acute dislocation occurred in $15 \%$, and became chronic in $9 \%$; there were femoral shaft fractures in $4.6 \%$ and these, with shaft perforation gave universally poor results. Nevertheless, $75 \%$ of patients had a satisfactory outcome, with worthwhile relief of pain. It would seem sensible to warn elderly patients and their relatives of the increased risks in this age group.
\end{abstract}

Whilst the results of total hip replacement are generally good, certain groups of patients do less well. Amongst these are elderly patients, particularly after femoral neck fracture (Coates and Armour 1980; Sim and Stauffer 1980). With an increasingly aged population, an increasing number of octogenarians are presenting for primary hip replacement and the results in this group merit attention.

\section{PATIENTS AND METHODS}

We reviewed the records of 113 consecutive patients aged 80 or more, who had a primary total hip replacement at Winford Orthopaedic Hospital between 1978 and 1985. The records of six were inadequate leaving 107 for analysis. We used the Harris hip score, but eliminated the assessment of movement (Table I). Pre-operative hip function was assessed retrospectively. Postoperative hip function was assessed from the patients themselves in 48 cases, and from surviving first degree relatives or attending family doctors for the remainder.

Statistical analysis. The Harris hip scores after complications were compared by Student's $t$-test and those before and after surgery by the Spearman rank test.

D. P. Newington, FRCS, Senior House Officer

G. C. Bannister, MCh Orth, FRCS, FRCS Ed(Orth), Consultant and Senior Lecturer

M. Fordyce. FRCS Ed. Orthopaedic Registrar

University Department of Orthopaedic Surgery, Southmead Hospital, Westbury-on-Trym. Bristol BS10 5NB, England.

Correspondence should be sent to Mr G. C. Bannister.

(C) 1990 British Editorial Society of Bone and Joint Surgery $0301-620 \times / 90 / 3078 \$ 2.00$

J Bone Joint Surg [Br] 1990; 72-B : 450-2.

\begin{tabular}{|c|c|}
\hline & Maximum \\
\hline Pain & 44 \\
\hline $\begin{array}{l}\text { Function } \\
\text { Limp } \\
\text { Distance } \\
\text { Support }\end{array}$ & $\begin{array}{l}11 \\
11 \\
11\end{array}$ \\
\hline $\begin{array}{l}\text { Activities } \\
\text { Stairs } \\
\text { Shoes socks } \\
\text { Sitting time }\end{array}$ & $\begin{array}{l}14 \\
14 \\
14\end{array}$ \\
\hline Total & 91 \\
\hline
\end{tabular}

\section{RESULTS}

The 107 patients had 112 hip replacements; the Charnley prosthesis was used in $85 \%$, the Howse in $9 \%$ and the Zimmer D in $6 \%$. The underlying disease was degenerative arthritis in $94 \%$ and rheumatoid arthritis in the rest. No patient had had a previous femoral neck fracture. Their mean age was 83.8 years and at the time of review some $70 \%$ were still alive. Mean follow-up was 3 years (range 3 months to 8 years).

Complications. Acute dislocation occurred in 17 hips $(15 \%)$, requiring open reduction in five and becoming chronic in 10 . The posterior approach had been used in 75 , the direct lateral in 17 , trochanteric detachment in nine, the anterolateral approach in six and was not recorded in five, but no consequent differences in rates of dislocation were found. There were five femoral fractures, four perforations of the femoral shaft and one acetabular fracture.

Four patients died of cardiopulmonary failure within 
14 days of operation. Thereafter the mortality was $4 \%$ per annum. Deep-vein thrombosis, acute confusion, decubitus ulceration and urinary retention were the commonest medical complications (Table II) and there was a surprisingly high incidence of intestinal obstruction. Seven patients had multiple complications.

The average time in hospital was 37 days, but patients who had sustained fractures of the femoral shaft remained for a mean of 149 days, and those who had postoperative dislocations for 71 days. The mean time in hospital for an uncomplicated case was 27 days.

Table II. Medical complications in 112 hip replacements in elderly patients

\begin{tabular}{ll}
\hline & Number \\
\hline Deep vein thrombosis & 15 \\
Pulmonary embolism & $5^{*}$ \\
Myocardial infarction & $4+$ \\
Urinary retention & 7 \\
Urinary tract infection & 4 \\
Acute confusion & 9 \\
Pressure sore & 7 \\
Intestinal obstruction & 6 \\
Bleeding duodenal ulcer & 1 \\
Chest infection & 3 \\
Hypothermia & 1 \\
Acute renal failure & 1 \\
\hline * one fatal \\
+ three fatal
\end{tabular}

Table III. Dislocation of hip replacement

\begin{tabular}{lllll}
\hline & & & \multicolumn{2}{c}{$\begin{array}{l}\text { Dislocation } \\
\text { (per cent) }\end{array}$} \\
\cline { 3 - 5 } Author & & Patients & Early & Recurrent \\
\hline Sim and Stauffer & 1980 & Femoral neck fracture & 11 & 2 \\
Khan et al & 1981 & General series & 2.1 & 1 \\
Present series & 1990 & Over 80 years of age & 15 & 9 \\
\hline
\end{tabular}

Pain relief and mobility. The average modified Harris hip score before operation was 32. After hip replacement, it was 35 for patients who had operative fractures, 37 in those with perforated shafts and 56 after dislocation. Uncomplicated cases scored a mean of 72 points. Where there was no operative complication, the final result related to the severity of symptoms before surgery.
Overall, $76 \%$ of the patients attained a modified Harris hip score of at least 60 and could be deemed to have a satisfactory outcome.

Patients who were heavily dependent before their operation fared as well as those who were more independent; we were unable to identify any group of patients with increased risk of complications.

\section{DISCUSSION}

Octogenarians who undergo hip replacement have an increased risk of complications. Rates of dislocation, femoral fracture and hospital mortality are all increased.

The reported dislocation rate following total hip replacement for femoral neck fracture varies between $8 \%$ and $11 \%$ (Coates and Armour 1980: Sim and Stauffer 1980) but we found an incidence of $15^{\circ}$, over seven times higher than the general experience in Bristol (Khan, Brakenbury and Reynolds 1981). The incidence of recurrent dislocation was over four times greater than the highest figure previously recorded (Table III).

Table IV. The snowball effect of complications in seven patients

\begin{tabular}{|c|c|}
\hline Orthopaedic problem & Medical problem \\
\hline Dislocation & $\begin{array}{l}\text { Hypothermia } \\
\text { Left ventricular failure } \\
\text { Haematemesis }\end{array}$ \\
\hline Dislocation & $\begin{array}{l}\text { Decubitus ulcer } \\
\text { Deep venous thrombosis } \\
\text { Urinary tract infection }\end{array}$ \\
\hline Fracture of femoral shaft & $\begin{array}{l}\text { Bowel obstruction } \\
\text { Deep venous thrombosis } \\
\text { Wound infection } \\
\text { Decubitus ulcer }\end{array}$ \\
\hline Dislocation & $\begin{array}{l}\text { Decubitus ulcer } \\
\text { Acute confusion }\end{array}$ \\
\hline Dislocation & $\begin{array}{l}\text { Acute renal failure } \\
\text { Acute confusion }\end{array}$ \\
\hline Dislocation & $\begin{array}{l}\text { Deep venous thrombosis } \\
\text { Pulmonary embolus }\end{array}$ \\
\hline Dislocation & $\begin{array}{l}\text { Complete heart block } \\
\text { Dy'srhythmia }\end{array}$ \\
\hline
\end{tabular}

The incidence of iatrogenic femoral shaft fractures was four times higher than the $0.9 \%$ previously reported from this unit (Khan and O'Driscoll 1977) and the outcome of this complication in the older patient was significantly worse, since they remained in hospital for a long period and often returned home with their original symptoms little changed.

Peri-operative mortality was over twice that for an average group of younger patients, but significantly less 
than that for patients of similar age in Bristol who had sustained a femoral neck fracture and undergone hemiarthroplasty (Sikorski and Barrington 1981). After the immediate postoperative period mortality was less and relatively constant, probably being unrelated to the procedure. Medical complications occurred in $48 \%$ of patients, but only $10 \%$ were life-threatening, half the incidence reported from Canada (Phillips et al 1987). Seven patients who sustained either a dislocation or a fracture also developed medical problems which snowballed; the resilience of this age group to complications is clearly limited (Table IV). Nevertheless, three-quarters of our patients emerged with a satisfactory result, which related more to pain relief than to improved mobility.

Octogenarians who seek elective hip replacement, and their families, should be advised of the age-related risk of the operation. This may temper their enthusiasm for the procedure and anticipa:e the disappointment if complications ensue.

No benefits in any form have been received or will be received from a commercial party related directly or indirectly to the subject of this article.

\section{REFERENCES}

Coates RL, Armour P. Treatment of subcapital femoral fractures by primary total hip replacement. Injury 1980; 11:132-5.

Khan MAA, Brakenbury PH, Reynolds ISR. Dislocation following total hip replacement. J Bone Joint Surg [Br] 1981; 63-B:214-8.

Khan MAA, O'Driscoll M. Fractures of the femur during total hip replacement and their management. J Bone Joint Surg [Br] 1977; 59-B:36-41.

Phillips TW, Grainger RW, Cameron HS, Bruce L. Risks and benefits of elective hip replacement in the octogenarian. Can Med Assn J 1987; 137:497-500.

Sim FH, Stauffer RN. Management of hip fractures by total hip arthroplasty. Clin Orthop 1980; 152:191-7.

Sikorski JM, Barrington R. Internal fixation versus hemiarthroplasty for the displaced subcapital fracture of the femur: a prospective study. J Bone Joint Surg [Br] 1981 : 63-B:357-61. 